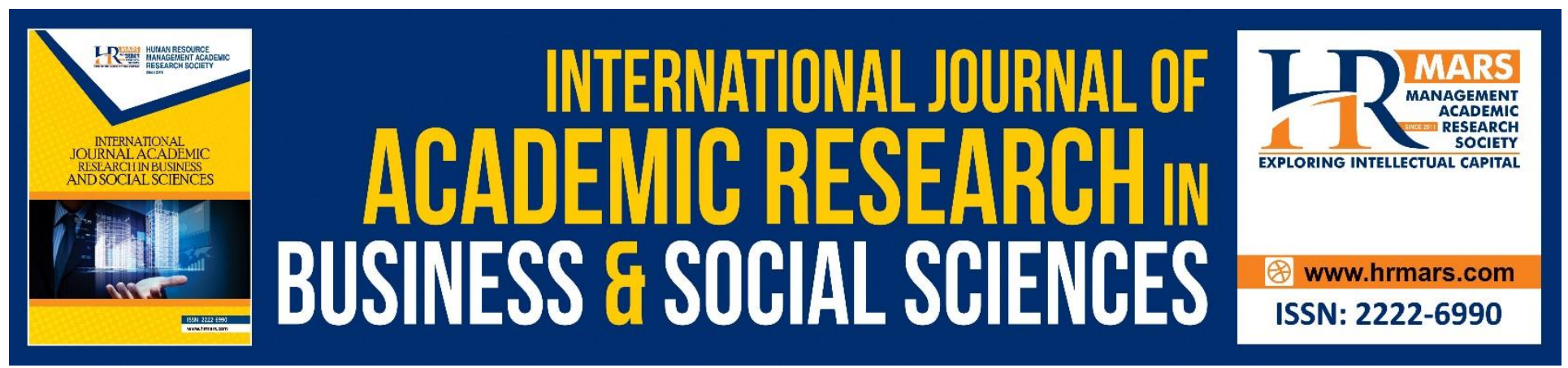

\title{
The Relation of Balaghah in the Qur'an verses with Islamic Faith
}

Roslan Ab Rahman, Wan Ismail Wan Abdullah, Nashaat Abdel Aziz Baioumy, Mohamad Zaidin Mohamad, Razali Musa, Muhammad Mahmud ‘Abd al-Qadir

To Link this Article: http://dx.doi.org/10.6007/IJARBSS/v8-i10/4727

DOI: $10.6007 /$ IJARBSS/v8-i10/4727

Received: 18 Sept 2018, Revised: 11 Oct 2018, Accepted: 16 Oct 2018

Published Online: 30 October 2018

In-Text Citation: (Rahman et al., 2018)

To Cite this Article: Rahman, R. A., Abdullah, W. I. W., Baioumy, N. A. A., Mohamad, M. Z., Musa, R., \& Al-Qadir, M. M. 'Abd. (2018). The Relation of Balaghah in the Qur'an verses with Islamic Faith. International Journal of Academic Research in Business and Social Sciences, 8(10), 218-225.

Copyright: (C) 2018 The Author(s)

Published by Human Resource Management Academic Research Society (www.hrmars.com)

This article is published under the Creative Commons Attribution (CC BY 4.0) license. Anyone may reproduce, distribute, translate and create derivative works of this article (for both commercial and non-commercial purposes), subject to full attribution to the original publication and authors. The full terms of this license may be seen

at: http://creativecommons.org/licences/by/4.0/legalcode

Vol. 8, No. 10, 2018, Pg. 218 - 225

http://hrmars.com/index.php/pages/detail/IJARBSS

JOURNAL HOMEPAGE

Full Terms \& Conditions of access and use can be found at http://hrmars.com/index.php/pages/detail/publication-ethics 


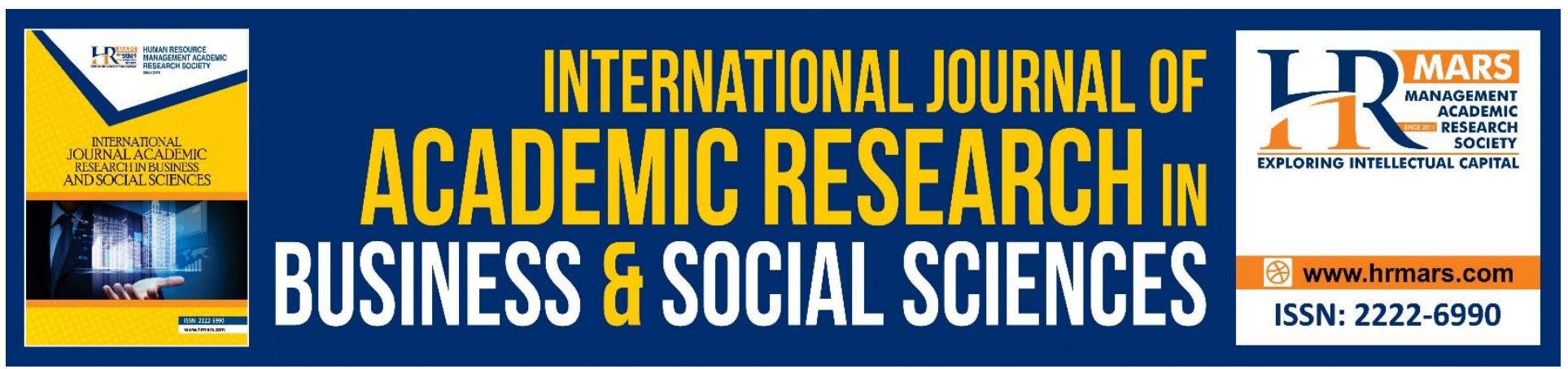

\title{
The Relation of Balaghah in the Qur'an verses with Islamic Faith
}

\section{${ }^{*}$ Roslan Ab Rahman, Wan Ismail Wan Abdullah, Nashaat Abdel Aziz Baioumy, Mohamad Zaidin Mohamad \& Razali Musa}

Faculty of Islamic Contemporary Studies, University of Sultan Zainal Abidin (UniSZA), Malaysia.

\author{
Muhammad Mahmud 'Abd al-Qadir \\ Faculty of Education, University of Cairo, Egypt.
}

\begin{abstract}
Balaghah plays an important role in explaining the true meaning of a Quranic verse especially relating to the Islamic faith. The study aims to show the role of knowledge in the Quranic verses relating to the creed. This is because if his interpretation does not meet the true requirements of the balaghah discipline, it can undermine the understanding of the Islamic faith. Some related Quranic verses that are believed to be taken to explain the important role played by knowledge in the interpretation of the verses that conform to the true aspects of the Islamic faith. In conclusion, the literal meaning of meaning cannot rely solely on reason or on the expression, it should also refer to the implied meanings. This is the science of balaghah especially in the category of majaz plays an important role in ensuring the meaning of the verse is not spelled out of the true faith.
\end{abstract}

Keywords: Balaghah of al-Qur'an, verses mutashabihat, role of balaghah.

\section{Introduction}

Definition of balaghah from the aspect of the term balaghah gives a great and clear meaning, with a true and eloquent phrase. It can affect one's heart and it also needs to be in line with the situation, condition and stage of the person being talked to. (al-Jarim \& Amin, 1959). From the aspect of the word balaghah word is a noun derived from the basic word:

بلغ - يبلغ - بلاغة (balagha - yablughu - balaghah) which means fasahah that is clear and clear (al-Razi, 1993). The word "afsahu al - subh" morning was bright and clear. Hence the eloquent word is a clear meaning, easy language and good arrangement.

Every word in a fluent word also needs to be in accordance with the grammar guidelines. (Ali, 1998) Someone who became eloquent (baligh) was also called al-Balaghi who was eloquent and able to convey something with his expression (Louis, 1986). "Fasuha wa hasuna bayanuh" which is 
eloquent and beautiful explanation or allegations (Mustafa, 1986). Scientifically, balaghah is a discipline based on the purity of the soul and the carefulness of the beauty and clarity of distinction between various expressions. As in Saudah's (1999) writings the language linguists equate balaghah with rhetoric. She states that Gorys Keraf in his book of Diksi and Language Styles has defined rhetoric as a traditional term for the language jewellery technique as the art of conversation or writing in a field of science or as a structured method which guided the construction of the verse to influence people's attitudes and feelings. Salmah (1999) that balaghah's knowledge is an interesting science as it equips one's conversations with beautiful words, meaning and style as we can summarize from the following definition, which is the science of how to choose a meaningful phrase and compose it in a way beautiful and use the words that fit the desired purpose.

Muhammad (2006) also mentioned the words of Syauqi Daif in his writings that the Arabian Jahiliyyah community had a high position in terms of balaghah and bayan as described by the Qur'an. Likewise, these people like to argue and have a very strong argument. For example, they want to invite their people to fight the Qur'an in terms of balaghah. The call was clear, indicating that they were given fluency or strength and strength using balaghah verses. It is narrated that al-Walid bin alMughirah, who was one against the Messenger of Allah, when he heard some of the Qur'anic verses, he said: "By Allah, I have indeed heard some verses from Muhammad which is not from the words of a man or "jin", it is very beautiful and flowering. Al-Suyuti (n.d.) has stated that the determination of the meaning meant for a reminder can not only depend on reason alone because it requires the sake of majaz.

The conclusion is that the knowledge of balaghah is necessary to help in understanding the true meaning of the Qur'anic verses when there is an element of majaz, parable and so on. As alZamakhshari, a well-known Arabic alphabet, was noted by Abdul Halim Hashim in his book "I'jaz alQur'an inda al-Baqillani": الا يستطيع لفهم أسرار القرآن إلا رجل برع في علوم البلاغة to understand the secrets of the Holy Qur'an unless it is truly proficient in the knowledge of balaghah. It can be concluded that the function of balaghah knowledge is very important in understanding the meaning of the Qur'anic verse especially the implicit meaning.

Definition of the Faith from the Arabic word "aqada" and the fraction of the word "aqd". He used the bond of agreement and the like. From this bond of artificially derives the word aidah which means bond or knot in ideology and belief (Mustafa, 1986). While the Islamic faith is to mean belief or faith in the essence or value of absolute, permanent and eternal as the teachings of the Quran and al-Sunnah to mankind. These holdings or beliefs will be tightly knit in the human psyche and are unlikely to decompose in any situation. It also has a strong resolve without any doubt and doubt (Sabiq, 1998).

The Islamic creed as summed up by Sabiq (1998) covers the six basic points that are about the pillars of faith. First, to trust Allah by referring to the greatness and majesty of Allah. Man can know Allah by using a sane mind that is to judge and think of the occurrence of this nature based on the verses of the Qur'an. Second, humans need to recognize God's power to survive the punishment of hell. Both, believe in the angels ordered by Allah to do the task entrusted to him. This gives confidence 
to believing people about good and evil or heaven and hell. Third, believe in the chosen prophets and apostles of the human race to carry out the trust and command of Almighty Allah, so that man always gets pleasure and blessings from Almighty Allah. Fourth, believe in God's books which are revealed to the prophets and apostles of His choice that bring about good and bad, halal and haram and the description of favors and wrongs. Fifth, believe in the hereafter that humans can regulate life in the world regularly as a supply to eternal eternity. It encompasses the debate about "al-Sam'iyyat" and its description is only available through God's revelation. Sixth, believe in qada 'and qadar ie God's destiny s.w.t whether it is good or bad. Man is encouraged to strive and to endeavor, and to pray and surrender to God. In other words, man only designs but Allah who determines.

In conclusion, what constitutes a determination of the heart and holds of a person is aqidah, whether it is true or false. Actually in discussing the verses of the Qur'an that relate the element of balaghah with the aspect of the creed, it is a debate contained in a topic called verses mutasyabihat and its acronym is muhkamat. Almighty Allah says; (Al Imran, 3:7)

" هو الذي أنزل عليك الكتاب منه آيات محكمات هن أم الكتاب وأخر متشابهات "

Ibn Habib al-Naysaburi states in mutashabih and muhkam disagreements, but the authentic Qur'anic verses are divided into verses of muhkam and mutashabih. Generally the mutashabihat verse carries two meanings, namely, the ambiguity that shows that it is incapable to distinguish between two things and it resembles one another (al-Suyuti, n.d.).

Ibrahim (2003) in the dissertation summarized the meaning of Mutashabihat in terms of terms to four things, namely:

1. The argument of something beyond the ability of reason as the essence of the substance and nature of Almighty Allah.

2. Knowledge such as unseen things like the moment of death.

3. It is difficult to determine its meaning because it can be assumed by various purposes.

4. Text that cannot be accomplished means like Muqata'ah in the beginning of surah.

In conclusion, the meaning and debate of the Mutashabihat verses are related to the interpretation of the words used in the view of the creed with the view of the knowledge of balaghah to achieve the harmony of the true meaning of the verse, and can safeguard from the misinterpretation of the true meaning of the Qur'an and the sanctity of Almighty Allah.

\section{Word of al-Mutsyabihat Related to the Place}

The Word of Allah s.w.t: الرحمن على العرش استوى (Taha, 20:5) "al-Rahman" (Allah) who sits on the throne". "Istawa" in a way worthy of him. Throne is a bed for the king (al-Mahalli \& Al-Suyuti, 1987). This verse is a kinayah about the government ie Almighty Allah. What is authentic, istiwa' is well-known and how the circumstances are unknown, asking about it as a heresy and believing in it is obligatory as said Imam Malik, istiwa' is worthy of the majesty of Almighty Allah (al-Zuhayli, 1991).

But according to al-Suyuti this verse is associated with the element of "tawriyyah" which refers to a word and there are two meanings or called "mujarradah" which has the meaning of near and far from one utterance. The word al-Zamakhshari, you can not see a chapter in the more 
INTERNATIONAL JOURNAL OF ACADEMIC RESEARCH IN BUSINESS AND SOCIAL SCIENCES Vol. 8, No. 10, Oct. 2018, E-ISSN: 2222-6990 @ 2018 HRMARS

elaborate and more polite al-Bayan knowledge, more useful and more helpful in bringing the verses of Mutashabihat in the Qur'an and hadith. As such verse, istiwa' has two meanings, first in one place that is called the meaning of almost but not that which is meant for the purity of Almighty God preserved. Both the meaning of commanding and possessing, that is the distant meaning (al-Suyuti, n.d.). He is the Almighty God on the Throne, man does not know how the situation even believes in Him, according to the tafwid al-Salaf al-Soleh approach who believe in His attributes without changing and reciting without comparisons and parables as istiwa 'it deserves for the greatness of Allah as His word; "يد الله فوق أيديهم" (al-Fath, 48: 10). This is because Allah does not have mass and resembles everything new and aristocracy is a creature we do not know the truth. While the Khalaf approach holds in mind the attributes of Allah that the istiwa' is istila' (possessed by the government), al-Tasarruf al-Kamil (makes perfect action), the arashi is the power and al-yad is kudrat (al-Zuhayli, 1991).

Some views say because of his fame and the similarity in government. As for the words, يد فلان مبسوطة ويد فلان مغلولة for a generous one and a fool although no one has a hand (al-Zamakhshari, 1987). Thus, with Almighty Allah it, can be concluded that it is not necessarily to say that it is based on the 'arash or singgahsana mentioned in Almighty Allah as human government, but what is meant is the government and authority of Almighty Allah and kinayah itself is a symbolic language that is not in the real meaning pronounce. This verse became a debate among Islamic scientist scholars. For al-Asha'irah (Sunnah wa al-Jamaah) the issue of the sanctification of Almighty Allah is forbidden to reject the misleading misconceptions known as al-mujassimah and al-mushabbihah where they say Almighty Allah resembles the creature, al-Ash 'ari hold fast to his opinion that every one of God is not the same as his creation. For them the word "al-istiwa" "indicates a trait for Almighty Allah and they say that this verse does not show that Allah is in the sky, when asked to pray lifting his hands towards the sky as the prayer is praying towards the Kaaba in Mecca and prostrating towards the earth does not mean Allah is in Mecca or on earth. That's why praying with hands to the sky does not mean that God is in heaven. Obviously, al-Asha irah denied that Allah had a place of "jihah" because they also denied that Allah has a mass because the masses need to be in place whereas all this is new and impossible to Allah s.w.t the Most Holy from resembling a being (al-Ghazali, n.d.).

It can also be seen through the word said: "وهو القاهر فوق عباده (al-An'am, 6: 18), أمنتم من في" " السماء (al-Mulk, 67: 6). According to al-Zamakhshari (1987), "fauqa 'ibadih" is an illustration of the power and height of Allah over His servants. While "fi al-sama" " means his government and power (sultanih wa qudratih) (al-Mahalli \& al-Suyuti, 1987). Thus it is clear that these verses are not meant to be merely verbal, but must be interpreted to mean the implicit (distant) meaning. Here shows the need to also rely on the study of meaning as the field of balaghah in explaining certain pronouncements in the al-Qur'an al-Karim.

\section{Word of al-Mutasyabihat Related to Body Parts}

The word "yad, a'yun ('ain) and wajh" which means the hands, eyes (eyes) and faces are pledged to God s.w.t while Allah s.w.t "laisa kamislihi syai' is not the same as everything new.

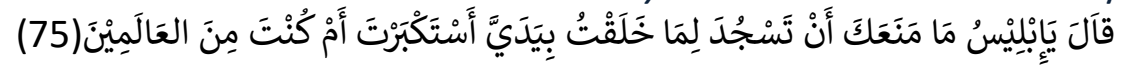


INTERNATIONAL JOURNAL OF ACADEMIC RESEARCH IN BUSINESS AND SOCIAL SCIENCES Vol. 8, No. 10, Oct. 2018, E-ISSN: 2222-6990 ㄷ 2018 HRMARS

(al-Sad, 38: 75).

There is a view that the word "yad" here means without intermediation. According to alZamakhshari also that both hands are indicative of one's actions as it is customary for every act to be performed by using the hand until the treatment is in the heart even though one does not have the hand as mentioned (al-Zamakhshari, 1987).

The word "yad" is also in the word of Allah: "يد الله فوق أيديهم"..." (al-Fath, 48: 10). From the aspect of the word "yad" means the meaning of al-sultan, al-quwwah and al-qudrah (power) ما لي لهذا الأمر يدان (Mustafa, 1986). The Word of Allah والسماء بنيناها بأيد "yad" means with power (al-Razi, 1993). He also "means the devotion made by the hand of the Prophet (PBUH) is referring to "yad" Allah. But Almighty Allah the holy of the members and the properties of the mass but the intentions of bonding the agreement with the Prophet (PBUH) like making the bond of the covenant with Allah (alZamakhshari, 1987). This verse is a ta'kid in the verse إنما يبايعون الله by "takhyil" (imigination) and tamthil (comparison). From the perspective knowledge of balaghah, it is called isti'arah makniyyah that is likened to the observation or supervision of Allah on the bond of their agreement (Hudaibiyyah) with the king who put his hand on the hands of his people. Obviously, he mentions mushabbah and removes mushabbah bih, but comes with a symbol that becomes the habit of a member of his hand in isti'arah makniyyah (al-Zuhayli, 1991). According to al-Alusi (n.d.) in his commentary rejecting Isti'arah in the name of Allah by means of tasrihiyyah (removing Mushabbah and mention mushabbah bih) even states that the verse was taken makniyyah for not putting the name of Allah by another name.

Clearly, the use of the words of Yad (hand) in this verse also means covering, victory, favors of guidance which is a majaz, but Allah swt is holy from any member, the nature of the masses, as the salaf of the salaf with the existence of the hand of Allah but not the hands creatures because Allah "laisa kamis/hi shay' "(nothing like him). Likewise also the hand when pledged to God is not the essence of the hand as a creature but in the verse refers to God as the trigger of the covenant (alMahalli \& al-Suyuti, 1987).

For al-Ash 'ari, the "yad" nature of Allah is a fact and worthiness of the Almighty. His views are similar to the views of al-Salaf al-Soleh. However, "yad" for Allah is not the same as what is for His creatures (al-Ash `ari, 1977). For those, Allah does not resemble a being based on Allah is qadim while the creature is a hadith (against qadim), if Allah has an element of equality with a creature, it is impossible for Allah to create all the occurrences of this earth (al-Ghazali, 1991). Whereas the alMu'tazilah, the word Yad was recited as a favor and al-Yadayn لما خلقت بيدي was also said to be alquwwah meaning strength (al-Jabbar, 1965). Obviously through the view of al-Ash 'ari based on this prophecy indicates that God is pure from all elements of equality with His creatures. Therefore, the convergence of the meaning exists between this aspect and the aspect of knowledge of majaz balaghah which placing a pronouncement not in the real meaning (zahir) as explained and the meaning of meaning is also seen to be based on the concept of majaz in balaghah knowledge. Furthermore, the word of Allah; "ويبقى وجه ربك" (al-Rahman, 55: 27). The word "wajh" is a form of 
INTERNATIONAL JOURNAL OF ACADEMIC RESEARCH IN BUSINESS AND SOCIAL SCIENCES Vol. 8, No. 10, Oct. 2018, E-ISSN: 2222-6990 @ 2018 HRMARS

Majaz Mursal, mentioning the part and which is intended as a whole. He is called 'alaqah juz'iyyah. This verse mentions the face, but the desired purpose is his substance (al-Suyuti, n.d.). The views of the Mu'tazilah say that the expression of the face is a concern about the substance of Allah. It is said also the reward, and the reward and the pleasure (al-Jabbar, 1965) They still denied the wajh attributed to the direction of seeing Allah because that direction brought the determination of mass while it is impossible for Allah as stated. The word wajh in other verses is like his word; ئرجيد..." " (al-Insan, 76: 9) and "إنما شيء هالك إلا وجهه" (al-Kahf, 18: 28). According to Ibn Kathir, God gives the character of wajh al- with "ذوجيء (ذوالجلال والإكرام "Zal-Zuhayli, 1991).

The word wajh here illustrates the meaning of the sacred substance of His substance, as the poor people of Mecca said: "Where is the glorious Arab face and who rescues me from the shame?". The face in these words is not means the faces of the Arabs, but the meaning of their own. The face here is a tashbih with their creatures about their conduct glorifying and raising Him rather than what is Allah (al-Zamakhshari, 1987). The Asians describe the word wajh through verses It means the nature of the substance for Allah where the meaning of wajh proves the existence of Allah. Even if they set wajh as the nature of Allah, but denied how wajh for Allah (al-Ash`ari, 1977).

\section{About See}

Almighty Allah says: "لاتدركه الأبصار وهو يدرك الأبصار" (al-An'am, 6: 103) means "It can not be seen by the eye sight while it is able to see all the eyesights (knowing the truth). The sight of God is covering every thing including from the sight of the eye is also not hidden from his sight. Al-Absar here is devoted to the tajnis conversation (al-Zuhayli, 1991). In the science of balaghah, tajnis or jinas is the meaning of the equation between two pronounces from the terms of reference but both are different from the point of its meaning. The tajnis in the verse are the tajnis tam category. According to al-Suyuti (n.d.), since the two pronouncements are the same when it comes to the first one meaning, then the second with one other meaning, one will enjoy it. This is what the so-called badi' knowledge is so beautiful and interesting in the Qur'an.

His word, لا تدركه الأبصار means he can not see Him. Ibn 'Abbas said: He can not be seen by human sight in this world, but they can see Him in the hereafter because there is a word of God about that which is His word; "وجوه يومئذ ناضرة, إلى ريها ناظرة (al-Qiamah, 75:22-23). Ru'yah Almighty Allah remains to the believer in the hereafter but without covering or comprehensively in the manner in which the situation is, for otherwise it should not be complied with the greatness of Almighty Allah in his words لا تدركه الأبصار because of nothing can to see it (al-Zuhaili, 1991). The Mu'tazilah people say it is impossible for man to see Allah based on the verse but different from the Sunnah wa alJamaah, it should be as the verses 23 al-Qiamat as mentioned (al-Zamakhshari, 1987).

\section{Conclusion}

In conclusion, the importance of the knowledge of the Qur'an in the Qur'an is obviously more and more verses relating to the Islamic creed. The term meaning cannot rely solely on reason or rely solely on the expression, it should also refer to the implied meanings. This is the science of balaghah especially in the category of majaz plays an important role in ensuring the meaning of the verse is 
INTERNATIONAL JOURNAL OF ACADEMIC RESEARCH IN BUSINESS AND SOCIAL SCIENCES

Vol. 8, No. 10, Oct. 2018, E-ISSN: 2222-6990 @ 2018 HRMARS

not spelled out of the true faith. This situation is clearly evident from the interpretations of the Qur'an from scholars such as al-Zamakhsyari, al-Alusi and scholars now al-Zuhayli who have always linked their interpretation with the elemental elements in reinforcing the true meaning. Similarly, aspects of Islamic faith such as al-Ash ari who represent Sunnah wa al-Jamaah members are always in line with what is described by the description of Arab balaghah knowledge. Topics calculated should be made in more detail to widen the exposure of Arab balaghah knowledge with the Islamic creed, so that the results are more obvious.

\section{Acknowledgement}

Special appreciations to the Research Management, Innovation \& Commercialization (RMIC), Universiti Sultan Zainal Abidin (UniSZA) \& the Faculty of Islamic Contemporary Studies (FKI, UniSZA) for sponsoring the project.

\section{Corresponding Author}

Roslan Ab Rahman, Centre for Studies of Education, Da'wah and Islamic Civilization, Faculty of Islamic Contemporary Studies, University of Sultan Zainal Abidin (UniSZA), Malaysia,

Email: roslanabr@unisza.edu.my

\section{References}

Al-Sharif, A. H. H. (1991). al-Baqillani wa Juhuduh fi l ’jaz al-Quran al-Balaghi. Cairo: al-Sadad li Khidmat al-Tiba'ah.

Al-Jabbar, 'Abd. (1965). Sharh Usul al-Khamsah. Egypt: Maktabah Wahbah.

Al-Alusi, S. D. (2008). Ruh al-Ma'ani fi Tafsir al-Qur'an al-'Azim wa al-Sab`al-Mathani. Cairo: Maktabah al-Tawfiqiyyah.

Al-Ash`ari, A. I. (1985). al-Ibanah `an Usul al-Diyanah. Beirut: Darul Kitab al-`Arabi.

Al-Ghazali, M. M. (n.d.). al-lqtisad fi al-l'tiqad. Egypt: Maktabah al-Jundi.

Al-Jarim, M. A. A. (1959). Dalil al-Balaghah al-Wadihah. Egypt: Dar al-Ma`arif.

Al-Mahalli, J. \& al-Suyuti, J. (1987).Tafsir al-Jalalayn. Egypt: Dar al-Rayyan li al-Turath.

Mustafa, I. (1986). Al-Mu'jam al-Wasit. Istanbul: Dar al-Da'wah.

Louis, M.Y. (1986). Al-Munjid fi al-Lughah wa al-A `am, (1986). Beirut: Dar al-Mashriq.

Abdullah, B. (2010).Tafsir Pimpinan al-Rahman. Kuala Lumpur: Darul Fikir.

Al-Suyuti, J. (n.d.). al-Itqan fi 'Ulum al-Qur'an. Cairo: Dar al-Turath.

Al-Zamakhshari, M. U. (1987). al-Kashshaf. Cairo: Dar al-Rayyan li al-Turath.

Muhammad, A. (2006). Penguasaan Pelajar Sekolah Menengah Agama Terhadap Pengajian IImu

Retorik Arab. UTM: Pusat Pengajian Islam dan Pembangunan Sosial.

Ibrahim, E. W. Z. E. (2003). Pemahaman Masyarakat Terhadap Sifat-sifat Mutasyabihat: Suatu Kajian Di Daerah Kuala Terengganu. UM: Akademi Pengajian Islam.

Al-Razi, M. (1993). Mukhtar al-Sihah. Beirut: Maktabah Lubnan.

Salmah, H. A. (1999). Ilmu Ma'ani: Kajian Perbandingan Dengan Bahasa Melayu. UKM: JPATI.

Sabiq, S. (1998). al- 'Aqa'id al-Islamiah". Trans. Rathomy, H.M.A. Kuala Lumpur: Pustaka Jiwa.

Saudah, H. S. (1999). Ilmu Bayan: Satu Perbandingan Dengan Bahasa Melayu. UKM: JPATI.

Al-Zuhayli, W. (1991). Tafsir al-Munir. Beirut: Dar al-Fikr al-Mu`asir. 